\title{
Estimation Of The Economic Impact Of Brain Drain On The Labor Expelling Country
}

Hisham H. Abdelbaki, University of Bahrain, Bahrain

\begin{abstract}
The emigration of human resources leads to many losses for the labor expelling country. Such losses would, without doubt, adversely affect the economic and social development programs in multiple aspects including state loss of migrants efforts in producing the desired growth whether in the planning and preparation stages or in the implementation stage and the cost opportunity represented in the financial resources spent on the migrants prior to their emigration which could have been utilized in other areas taking into account, the limited financial resources in the underdeveloped countries which are mainly labor expelling countries. Hence, the loss of such countries is doubled. They neither benefited from their labor after years of spending in education and health, nor they saved their funds and exploited in other alternatives like improving education and health services, providing job opportunities for residents, improving the innovation climate or even increasing civil production to improve the living standards of individuals. The study is devoted to analyze and measure of economic effects of labor emigration in the labor expelling economy, through taking Egypt - the largest Arab country suffering from this phenomenon-as an example and using data derived from Egyptian sources. Estimates have emphasized growing losses generated by the Egyptian labor emigration, especially by brain drain. The paper concludes that measures and policies must be adopted to stop this drain by addressing the causes of labor emigration or rather, the existing properties of the labor expelling country. Also, efforts must be made to ensure that data related to immigration is always available, updated and estimated by official bodies having human, financial and technical capabilities for this task.
\end{abstract}

Keywords: emigration, economic impact, brain drain, labor expelling country, remittances.

\section{FIRST: INTRODUCTION AND RESEARCH OBJECTIVE}

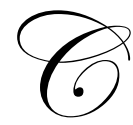

ontemporary literature on growth stressed the importance of the human factor as a basic element of production on the one hand and the increasing return of knowledge as a source of long-term economic growth on the other hand. Based on that, successive studies have confirmed the vital role of education in eradicating poverty and underdevelopment (Romer, 1986, 1987 and Lucas, 1988). Even though underdeveloped countries suffer from a lack of skilled labor, large numbers of their skilled labor are migrating to work in developed countries in a phenomenon referred to in economic literature as the 'Brain Drain' or 'Migration of Brains' or other terms which means the migration of skilled labor from the country of birth to work in developed countries especially the United States, Europe and Canada, this phenomenon has started to gain attention since the sixties. Despite addressing the importance of the human factor in the growth and development, it is noted that the Endogenous Growth theory had overlooked the migration of human capital. The study of Haque and Kim, 1995 is considered an exception to this where they integrated the brain drain from underdeveloped countries to developed countries in an endogenous growth model.

The emigration of human resources leads to many losses for the labor expelling country. Such losses would, without doubt, adversely affect the economic and social development programs in multiple aspects including state loss of migrants efforts in producing the desired growth whether in the planning and preparation stages or in 
the implementation stage and the cost opportunity represented in the financial resources spent on the migrants prior to their migration which could have been utilized in other areas taking into account, the limited financial resources in the underdeveloped countries which are mainly labor expelling countries. Hence, the loss of such countries is doubled. They neither benefited from their labor after years of spending in education and health, nor they saved their funds and exploited in other alternatives like improving education and health services, providing job opportunities for residents, improving the innovation climate or even increasing civil production to improve the living standards of individuals.

Egypt is considered one of the largest losing countries as a result of brain drain. According to the numbers of the central agency for public mobilization and statistics, the number of Egyptian immigrants in 2003 was eight hundred and twenty four thousand. Out of those, three hundred and eighteen thousands qualified Egyptians reside in the United States, hundred and ten thousands in Canada, seventy thousands in Australia and thirty five thousands in Great Britain. Those qualified immigrants work in critical and strategic fields such as surgery, nuclear engineering, laser science and tissues technology.

One study confirmed that $12 \%$ of the total Egyptian envoys abroad to obtain a doctorate do not return to work in Egypt and prefer to work in the destination country. During the period from 1970 to 1980, only $70 \%$ of the delegates to the United States returned to Egypt. In spite of the loss resulting from labor migration in general and skilled labor in particular, the number of studies in this area does not reflect the importance and seriousness of its consequences, perhaps there is no detailed study to estimate the loss resulting from brain drain. Hence, this study aims at measuring the economic impacts of Egyptian brain drain.

\section{SECOND: IMPORTANCE OF THE RESEARCH}

The importance of the research may be viewed from many angles:

1- $\quad$ Most of the studies have dealt with the explanation and measurement of the destination country's benefits from the brain drain.

2- $\quad$ On the other hand, few studies only were devoted to clarify the losses resulting from brain drain on the employment expelling country, mostly in a theoretical context without measuring such losses.

3- To estimate the rate of immigrants flow to the destination countries and the aggregate migration rate of the employment expelling countries, most of available studies have relied on data driven from destination countries statistics (for example, Docquier F., O. Lohest and A. Marfouk, 2005; Carrington and Detriagach, 1998 and Mishra, P., 2006).

Hence, the current study comes to fill these gaps through the explanation and measurement of losses due to brain drain on the employment expelling economy, through taking Egypt - the largest Arab country suffering from this phenomenon- as an example and using data derived from Egyptian sources.

\section{THIRD: THEORETICAL FRAMEWORK.}

\section{1- What are the characteristics of the brain expelling countries?}

The important Question is whether there are any common characteristics for the labor expelling countries especially skilled labor? And if this was the case, what specifically are those characteristics? In fact, economic literature has not really answered these questions directly, which means that there is no study devoted to explain and analyze the characteristics that contribute to the brain drain from a certain country, or what are those characteristics possessed by a country that make human brains attracted to that country. In spite of that, there are many studies which indirectly showed those characteristics in the context of its examination to brain drain, or other issues related to human migration in general, like migrants remittances and other issues.

Here, we are trying to draw those common characteristics that drive labor especially skilled one to migrate from a certain country, such characteristics are detailed below: 1- low level of wages and general living standards, especially that the wages of university graduates fall under the fixed wages category which suffer from a relative 
decrease when compared with salaries and wages of other society groups and they are subjected to a decline in their actual values with the continuous rise in the prices (Hassan, Saad, 2005). This reasons leads to lack of motivation to research and acquire knowledge, and the researcher finds himself facing two options, either to take another income generating job to improve his standard of living, or to migrate abroad. 2- lack of appreciation and recognition of scientists and researchers. 3- lack of research and development infrastructure, where researchers usually have better equipment, staff and funding in destination countries than in their native ones. 4- lack of proper innovative climate which is considered a cause and consequence at the same time, where the lack of innovative climate leads to a brain drain and the brain drain adversely affects the innovative climate in the native country, contrary to this is the case at the destination country as will be explained later. And finally, 5- political and economic instability.

\section{2- $\quad$ Economic Impact of Brain Drain on labor Expelling Countries}

This part deals with the gains and losses resulting from labor emigration in general and brain drain in particular on the source country or labor expelling country (Borjas, 1995).

\section{2/1 Losses resulting from labor emigration:}

There is no doubt that labor migration in general causes many negative effects to the national economy. Here we are trying to reflect the losses in economic welfare as measured by losses in the gross domestic product (GDP) resulting from non-migrant labor (labor remaining in the national economy) assuming that the remaining influencing factors other than labor migration remain unchanged, and assuming that the gross national product depends on the two production factors: work and fixed production as indicated in the following production function:

$Q=f(L, K)$

Where $\mathrm{Q}$ indicates the GDP, $\mathrm{L}$ indicates work factor used in production processes and $\mathrm{K}$ indicates the fixed production factor which, supposedly, can not be transferred out of the national economy. Using the simplified supply and demand model on the work factor to explain the impact of national labor migration on economic welfare as indicated in figure (1). The curve $\left(\mathrm{S}_{1}\right)$ represents the supply of labor in the national economy which is constant during this period, while curve (ZZ) represents the demand for labor which also reflects the marginal product of labor. Point $(\mathrm{N})$ is the equilibrium point in the labor market prior to the labor emigration thus the labor supply and demand is $(\mathrm{M}+\mathrm{K})$ and the prevailing wage level is $(\mathrm{C})$ which is equal to the marginal product of labor. Labor emigration leads to a decline in the supply of labor shifting the supply curve to $\left(\mathrm{S}_{2}\right)$ and hence wages increase to (D).

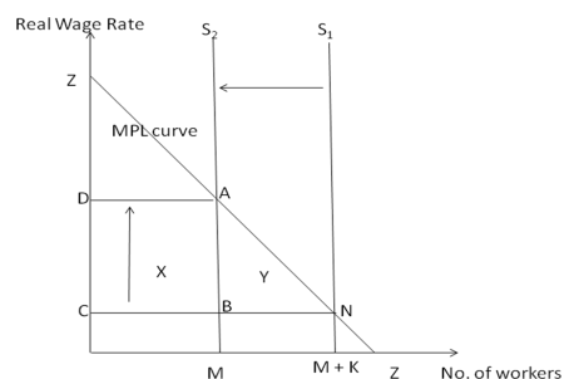

Figure (1) Losses resulting from labor emigration

Area C, D, A, B (Area of rectangle X) represents gains of labor remaining in the economy due to the increase in the level of wages. This can be calculated using the formula:

$\mathrm{G}_{\mathrm{L}}=\mathrm{L}_{\mathrm{GDP}} \mathrm{M}_{\mathrm{LF}} \mathrm{E}_{\mathrm{w}}\left(1-\mathrm{M}_{\mathrm{LF}}\right)$

GL indicates non-migrant labor in the economy, LGDP indicates labor participation in the GDP, MLF indicates the proportion of migrant labor to the total labor force in the economy while EW refers to wage flexibility of work force 
and is measured by dividing relative change in wages over the relative change in the work force while owners of the fixed production factor lose the area of $\mathrm{C}, \mathrm{D}, \mathrm{A}, \mathrm{N}$ (Area of rectangle $\mathrm{X}+$ Area of triangle Y) which could be calculated using the formula:

$\mathrm{L}_{\mathrm{O}}=\mathrm{L}_{\mathrm{GDP}} \mathrm{M}_{\mathrm{LF}} \mathrm{E}_{\mathrm{w}}\left(1-1 / 2 \mathrm{M}_{\mathrm{LF}}\right)$

In general, the state loss is represented in the area BAN (Area of triangle Y) which could be calculated by the formula:

$\mathrm{EL}=1 / 2\left(\mathrm{~L}_{\mathrm{GDP}} \mathrm{M}_{\mathrm{LF}}^{2} \mathrm{E}_{\mathrm{w}}\right)$

The previous simplified analysis includes only the direct loss of brain drain, but the brain drain causes other losses to the national economy as explained later.

\section{2/1/1 External Effects of Brain Drain.}

Migrant labor includes skilled and unskilled ones. The migration of skilled labor does not only affect through the reduction in supply of labor and the increase in the level of wages and thus, the loss indicated in the previous figure, but also through the impact on the national unskilled labor, meaning that skilled labor have positive impact on unskilled ones and that their migration out of the national economy would cause losses resulting from the reduction of productivity of the remaining non-migrating labor, that is a reduction of the marginal product of labor remained in the national economy. In view of figure (2), the reduction of the marginal product of labor would mean a shift in the marginal product curve to the left causing more aggregate loss to the economy where area ZQPA is added to the previous loss of the economy due to brain drain. Area ZQPA reflects losses resulting from external effects of brain drain. In this case, the equation (4) may be rewritten to reflect the loss of the national economy as result of brain drain only without the integration of losses resulting from the external effects of brain drain as follows:

$\mathrm{EL}_{\mathrm{SK}}=1 / 2\left[\left(\mathrm{~L}_{\mathrm{GDP}}\right)_{\mathrm{SK}}\left(\mathrm{M}_{\mathrm{LF}}^{2}\right)_{\mathrm{SK}}\left(\mathrm{E}_{\mathrm{w}}\right)_{\mathrm{SK}}\right]$

The loss of the national economy including loss resulting from the external effect of brain drain can be calculated using the following equation:

$\mathrm{EL}_{\mathrm{SK}}=1 / 2\left[\left(\mathrm{~L}_{\mathrm{GDP}}\right)_{\mathrm{SK}}\left(\mathrm{M}_{\mathrm{LF}}^{2}\right)_{\mathrm{SK}}\left(\mathrm{E}_{\mathrm{w}}\right)_{\mathrm{SK}}\right]+\left[\Phi\left[\left(\mathrm{L}_{\mathrm{GDP}}\right)_{\mathrm{SK}}\left(\mathrm{M}_{\mathrm{LF}}\right)_{\mathrm{SK}}\right] / 1-\Phi\right]\left[1-\left[\left(\mathrm{L}_{\mathrm{GDP}}\right)_{\mathrm{SK}}\left(\mathrm{M}_{\mathrm{LF}}\right)_{\mathrm{SK}}+\left[\Phi\left[\left(\mathrm{L}_{\mathrm{GDP}}\right)_{\mathrm{USK}}\right.\right.\right.\right.$ $\left.\left.\left(\mathrm{M}_{\mathrm{LF}}\right)_{\mathrm{SK}}\right] / 1-\Phi\right]\left[1-\left[\left(\mathrm{L}_{\mathrm{GDP}}\right)_{\mathrm{USK}}\left(\mathrm{M}_{\mathrm{LF}}\right)_{\mathrm{SK}}\right]\right.$

Where (LGDP) USK and (LGDP) SK represents the unskilled and skilled labor contribution to the GDP respectively. The second and third limits indicate the external effects on the skilled and unskilled labor remaining within the economy respectively (Borjas, 1995; and Mishra, P., 2006).

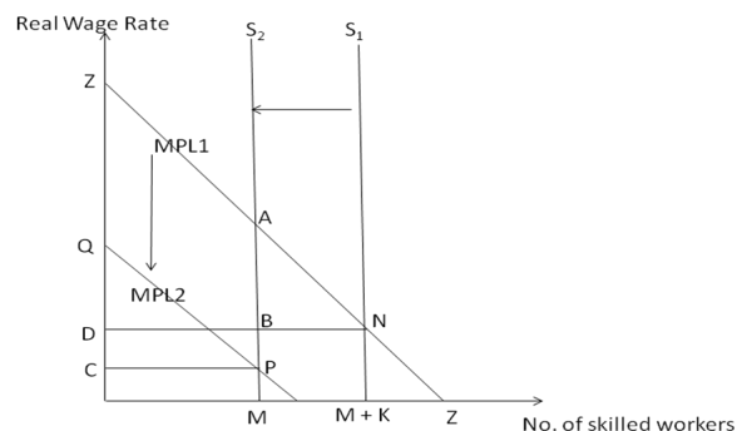

Figure (2) Losses resulting from brain drain 


\section{2/1/2 Opportunity Cost of brain drain due to losses in educating and health caring of migrants prior to their emigration.}

Every migrant serves a number of years in the educational process enjoying a health cover prior to his migration, hence, the labor expelling country losses all the funds spent on the education and health of migrants. We believe that the migrant's contribution in the destination country is the same as the loss sustained by the expelling country. But, despite the obviousness of the loss, the process of estimating it requires a huge amount of data and assumptions since there are no primary source data (Docquier, F., and A. Marfouk, 2006).

\section{2/1/3 Losses of taxes to the national economy as a result of labor emigration.}

The loss caused to a labor expelling country as a result of loosing tax revenues that could have been derived from labor in the absence of migration differ from one country to another according to the tax system approach and philosophy, as well as economic and social factors affecting tax revenues in the national economy. As a result, the process of estimating these losses is not an easy process and needs personal data and opportunity cost calculations and is in itself a complex process.

2/1/4/ Losses of the national economy as a result of loosing the efforts and expertise of migrant scientists in forming the next generation of researchers.

Many writers neglect the loss caused to the labor expelling country as a result of failing to take advantage from the expertise of its scientists to form the next generation of researchers and scientists, which is difficult to express in quantum.

\section{2/1/5 Negative loss on innovation and, technical and scientific research.}

Estimation of the skilled labor contribution to inventions in the host country was addressed by many studies through the use of an ideas production function which can be written as follows (Chellaraj, G., Maskus, K. E., and A. Mattoo, 2006):

$\mathrm{I}={ }^{\Phi} \mathrm{H}_{\mathrm{A}, \mathrm{t}}^{\mathrm{o}} \mathrm{A}_{\mathrm{t}}^{\lambda}$

Where I represent the number of new ideas, A represents the stock of knowledge in the country and $\mathrm{H}$ represents the human resources and other scientific inputs. Coefficient $\lambda$ represents the prior knowledge in the form of new ideas, if $\lambda$ is greater than zero, then the prior knowledge is positive, but if the coefficient is less than zero, this would mean that the proceeds of prior knowledge is in decline and process of producing new ideas is difficult. Coefficient ${ }^{\ominus}$ indicates the elasticity of new ideas with regard to scientific inputs. Finally, coefficient ${ }^{\circ}$ indicates the overall productivity which reflects the capability of the national economy to transform the previous inputs and knowledge into new ideas. Many studies have divided the scientific inputs into different variables like the proportion of foreign graduates from the total number of graduates in the country, the proportion of skilled labor immigrants from the overall work force, the cumulative number of doctors, scientists and engineers as a proportion from the total work force, the real expenditure on research and development, the cumulative number of inventions that have been funded and others. The gains if the destination country due to brain drain might be considered as losses to the expelling country the fields of inventions and technical and scientific research assuming the presence of the same innovative climate and capabilities in the expelling country. One applied study suggested that the existence of foreign graduates had a positive contribution with future inventions. The study confirmed that a $10 \%$ increase in the number of foreign graduates of the total number of graduates would increase the award of patents and inventions from universities and awarding from other institutions by $4.8 \%, 6 \%$ and $6.8 \%$ respectively. The study also made clear the presence of a positive, though weak, relationship between the number of skilled immigrants as a proportion of the overall work force in the United States and the development of new ideas. It also showed that a $10 \%$ increase in the number of skilled immigrants increases patents by $1.3 \%$ and number of university scholarships by $1.3 \%$. 


\section{2/1/6 Losses associated with remittances of immigrants.}

Some studies acknowledged that remittances of immigrants have a negative impact on economic growth through its negative impact on the overall productivity of the production factors on the one hand and on the other hand exercise their conversion effects on the response of the labor market and the product of technical progress and thus affect the economic cycle. This can be explained through the use of supply of and demand for labor (Chami, R., 2008).

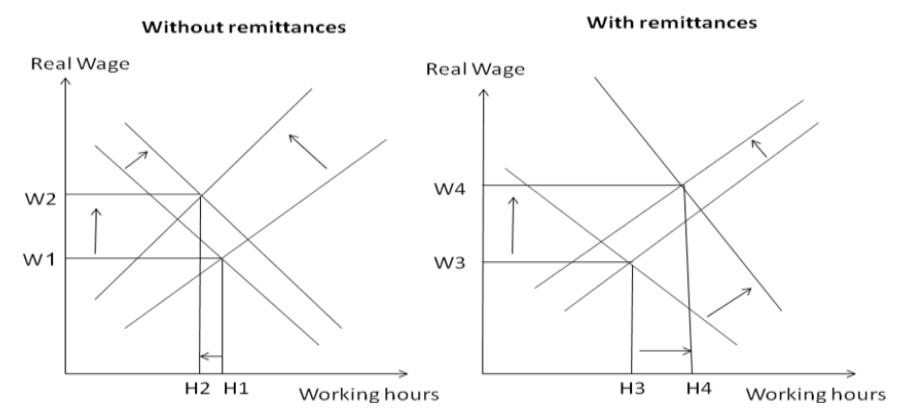

Figure (3) impact of migrant's remittances on some variables of the economy

In the absence of migrant's remittances, the labor market is equilibrated at real wage level (nominal wage divided by price level) and employment level. Assuming the occurrence of a technical progress, the labor market would respond to that by increasing the demand for labor, and as a result, labor would ask for a higher real wage for the same previous number of working hours then the supply of labor decreases and the equilibrium occurs at a lower employment level and a higher real wage. In the presence of migrant's remittances, the impact on demand for labor would be greater and the labor curve moves to a level higher than that when there were no remittances. On the other hand, the response of labor supply is lower than in the absence of remittances, and thus the supply of labor reduces less due to the contribution of remittances on the consumption and welfare of home labor (figure 3). Governments take different policies to absorb the impact of remittances on domestic consumption, most important are the tax policies, where the government may use taxes on consumption or taxes on work to limit the negative impact of these remittances. There is no doubt that using any of the two tax policies has extended effects on the prices, production, employment and income that could be multiplied by various multipliers in the national economy (Lucas, 1987; Cooley and Hansen, 1991; and Aiyagari, et al, 1998). Studies have proved that the impact of remittances on the welfare depends on comparing the marginal gains of such remittances with the marginal loss resulting from the associated volatility in the national economy in addition to the tax policies in place.

\section{2/2 Gains resulting from labor migration}

Are there any gains to the brain expelling economy? Some literature had listed some gains for a labor expelling country from the brain drain, here; we can number the gains that have beset with labor migration as well as gains of non-migrating labor as follows:

\section{2/2/1 Remittances to the source country}

One gain that can accrue to the national economy due to brain drain is the remittances made by migrants to their original country. Those remittances are viewed as compensation to mitigate the negative impacts of brain drain (Burgess, R. And V. Haksar, 2005). Migrants' remittances are defined as the value of cash transferred by migrants to the parent country for a period more than one year. Such transfers are recorded as (current transfers) in the current account in the balance of payments in the statistical yearbook of the International Monetary Fund (IMF). Studies on migrant's transfers include measurement of remittances from workers abroad, compensation of employees and migrant's remittances. The difference between these is that compensation of employees means the total earnings of foreigners residing abroad for less than twelve months, including all the benefits gained such as housing and tax- 
exemption, and are recorded under a sub-account named "income" in the current account of the balance of payments of the IMF. The migrants' transfers indicate the net wealth of a migrant who has moved from one country to another, and are recorded under "Capital transfers" in the capital account of the balance of payments of the IMF.

It is worth mentioning that remittances do not include transfers made through informal channels like the movement of funds through friends or relatives or by hand or even the so-called bill of exchange.

Remittances of workers abroad have increased steadily, particularly from the beginning of the nineties and, have become an important component of the balance of payments of the labor expelling countries, when compared to other forms of external flows like foreign direct investments, official aid and private capital flows (Chami, R., 2008). The level of remittances has increased from 48 billion U.S. dollars in 1994 to 114 billion U.S. dollars in 2003 (The World Bank, 2006).

No doubt that the remittances of workers abroad have multiple effects on the economic variables in both the expelling and destination countries. The flow of remittances from workers abroad leads to increase welfare and consumption for their families in the expelling country, and thus could contribute to the alleviation of poverty levels. These transfers also contribute to the alleviation of public debt burdens thus enabling the government to expand borrowing or current debt serving without taking any recessionary policies in the national economy. The possible new loans could be used to improve the infrastructure of the national economy or to increase spending on education and health whether through government efforts, or through aiding the private sector's efforts (Kannan and Hari, 2002; Adelman and Taylor, 1990; and Glytsos, 1993).

In summary, the effects of remittances flow on the labor expelling country differ from one country to another depending on many interrelated factors and, therefore, to identify the effects of such transfers would require these to be studied as separate cases which requires the availability of huge data often not available in the expelling countries especially that most of these countries are underdeveloped and suffer from lack of data on one hand and inaccuracy on the other.

\section{2/2/2 Transferring knowledge and technology from the host country to the expelling country.}

Some studies determine that migration of labor allows for the transfer of knowledge and technology to the parent country. However, here we recognize that the majority of knowledge and technology is transferred in there various forms through international trade and foreign direct investment and is not often linked to the brain drain (Abdelbaki, H, 2008). If the intention is that the migrants themselves transfer their knowledge and experience to their native country through their relatives and family, we see that the effect is weak.

\section{2/2/3 Alleviation of unemployment rate in the labor expelling countries.}

No doubt that migration of labor from the expelling countries allows these countries more employment opportunities for the remaining labor in the country, but this impact were referred to as a gain for the non-migrating labor through the former commentary. It also has a negative impact, where the owners of other production factors may have to employ less skilled and thus less productive labor.

\section{2/2/4 Allowing the flow of foreign direct investment}

Some of the studies decided that labor migration contributes to the flow of foreign direct investment to the parent country, but we decide that the inflow of foreign direct investment depends on many other objective factors, the most important of those factors are political, economical and legal stability in the country and, there is no doubt that such stability is not available in the labor expelling country. Therefore, we question the impact of brain drain on the flow of foreign direct investment. 


\section{3- $\quad$ Egyptian Brain Drain}

At first, the researchers would like to indicate the absence of a through study on the size of economic impact of Egyptian brain drain on the Egyptian economy, as a whole and, on scientific research and other various economy variables in particular. To identify the phenomenon of brain drain in Egypt, we shall consider the following points:

\section{3/1 Characteristics of Egyptian migrating labor.}

In this part, we consider the Characteristics and development of the migrating Egyptian labor as follows:

\section{A-Educational status}

Table (1) indicates that the proportion of graduates and post graduates represent almost half of all immigrants and , stands at more than half in the years 2002,2003,2006 ,and 2007 . Undoubtedly, Egypt is incurred millions of Egyptian pounds in order to educate these immigrants and ultimately does not benefit from them, and they migrate and contribute their efforts and experience in the development of other countries.

Table (1) Development of the number of immigrants according to educational status (1998 - 2007)

\begin{tabular}{|c|c|c|c|c|c|c|c|}
\hline Year & $\begin{array}{c}\text { Post } \\
\text { graduated }\end{array}$ & Graduated & $\begin{array}{c}\text { Intermediate and } \\
\text { above intermediate } \\
\text { education }\end{array}$ & Uneducated & Total & $\begin{array}{c}\text { Post and } \\
\text { graduate } \\
\text { \% of the } \\
\text { total) }\end{array}$ & $\begin{array}{c}\text { Intermediate, above } \\
\text { intermediate } \\
\text { education and } \\
\text { uneducated }((\% \text { of } \\
\text { the total })\end{array}$ \\
\hline 1998 & 34 & 359 & 367 & 41 & 801 & 0.49 & 0.51 \\
\hline 1999 & 29 & 274 & 336 & 32 & 671 & 0.45 & 0.55 \\
\hline 2000 & 28 & 243 & 233 & 32 & 536 & 0.51 & 0.49 \\
\hline 2001 & 31 & 322 & 334 & 31 & 718 & 0.49 & 0.51 \\
\hline 2002 & 31 & 274 & 323 & 24 & 652 & 0.47 & 0.53 \\
\hline 2003 & 8 & 167 & 104 & 14 & 293 & 0.60 & 0.40 \\
\hline 2004 & 28 & 200 & 115 & 14 & 357 & 0.64 & 0.36 \\
\hline 2005 & 29 & 196 & 180 & 20 & 425 & 0.53 & 0.47 \\
\hline 2006 & 23 & 210 & 124 & 11 & 368 & 0.63 & 0.37 \\
\hline 2007 & 23 & 198 & 145 & 7 & 373 & 0.59 & \\
\hline
\end{tabular}

Source: CAPMAS, Statistical Yearly Book, different issues.

Figure (4) shows the migration of a special category of Egyptian labor which includes holders of Ph.D., master's degrees and higher diplomas and thus increasing the loss of Egyptian economy due to the migration of this category.

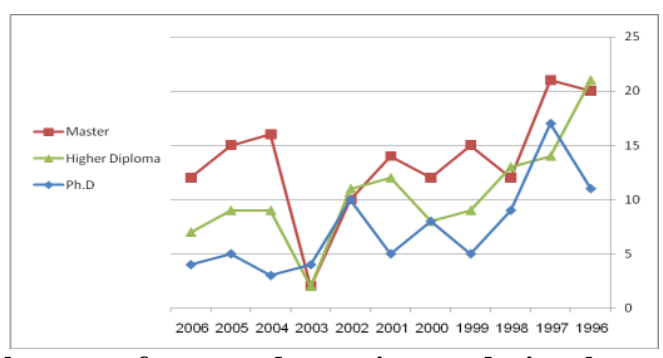

Figure (4) Development of post-graduate migrants during the period 1998 -2007.

Source: CAPMAS, Statistical Yearly Book, different issues. 


\section{B-Age of migrants}

Figure (5) indicates the Egyptian migrant's ages according to destination country in 2007, where the United States appropriates the lion's share of the migrants followed by Canada. Analyzing the figure, we find that the majority of the migrants are of working age and, are therefore an active work force with reduced support burdens and, who actively contribute to production, growth and progress in the destination country.

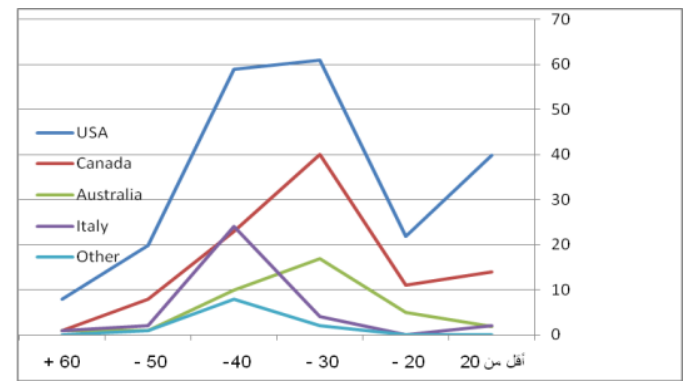

Figure (5) Number of migrants according to age category at the time of migration and, the destination country in 2007. Source: CAPMAS, Statistical Yearly Book, different issues.

\section{C-Destination country}

The Egyptian brain drain, as shown in table (2), is distributed between the United States with a percentage of 30\% of the overall Egyptian migrants in 2001 and, 75\% in 2004. Canada comes second in attracting Egyptian labor then Italy, Australia and other countries. The reason behind the declined numbers of Egyptian immigrants is the strong measures taken by most countries after the September 11, 2001 events in the United States.

Table (2) Egyptian migrants according to their destination 1998 - 2007

\begin{tabular}{|c|c|c|c|c|c|c|c|c|c|c|}
\hline Year & USA & Canada & Italy & Australia & Newsstand & Germany & UK & France & others & Total \\
\hline 1998 & 415 & 193 & 177 & 39 & 21 & 12 & 8 & 7 & 5 & 879 \\
\hline 1999 & 305 & 213 & 168 & 19 & 10 & 3 & 3 & 4 & 3 & 730 \\
\hline 2000 & 257 & 152 & 113 & 26 & 14 & 4 & 4 & 5 & 11 & 590 \\
\hline 2001 & 226 & 185 & 308 & 22 & 10 & 2 & 3 & 3 & 2 & 764 \\
\hline 2002 & 174 & 0 & 323 & 20 & 8 & 7 & 4 & 3 & 5 & 544 \\
\hline 2003 & 133 & 0 & 39 & 19 & 6 & 3 & 4 & 2 & 0 & 206 \\
\hline 2004 & 196 & 0 & 19 & 35 & 1 & 2 & 0 & 2 & 5 & 260 \\
\hline 2005 & 240 & 141 & 22 & 49 & 0 & 1 & 1 & 1 & 1 & 456 \\
\hline 2006 & 205 & 126 & 25 & 30 & 2 & 1 & 2 & 2 & 3 & 396 \\
\hline 2007 & 210 & 97 & 33 & 36 & 3 & 0 & 3 & 2 & 3 & 387 \\
\hline
\end{tabular}

Source: CAPMAS, Statistical Yearly Book, different issues.

\section{3/2 Development of remittances from Egyptian workers abroad}

One of the results of the Egyptian open door policy in the seventies of the last century is that Egypt became a primary source of labor. Most of the Egyptian migration-according to the preceding tables - was to Arab countries, particularly the Gulf region. Migration reach its peak in 1985 and, then decreased due to falling oil prices in the nineties of the same century and, due to the policy of replacing foreign labor by national labor which was adopted by some of Arab countries (Radwan, 2002). As a result to that, remittances of Egyptian labor in Arab countries represented an important component of the total remittances of Egyptians working abroad. Such remittances reached their peak in 1996/1997 due to increased oil prices and, started to decline after that (figure 6). 


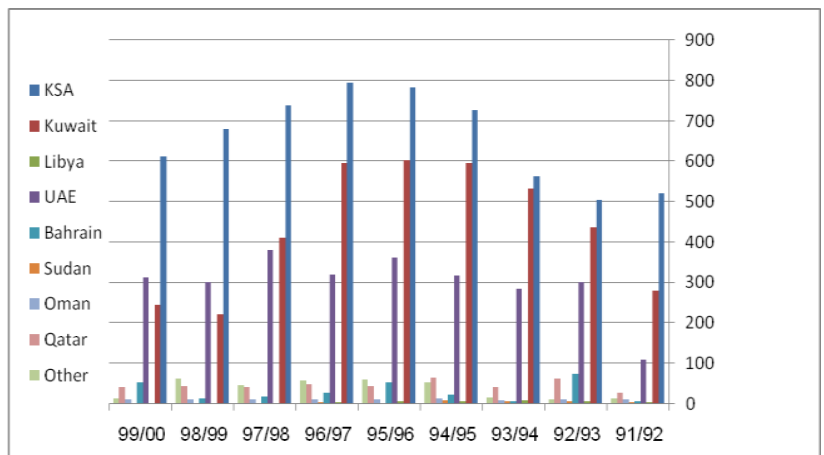

Figure (6) Development of remittances from Egyptians working in the Arab countries (million U.S.\$) d

Source: Egyptian economy report, "way of Egyptian economic growth", Economic researches forum, December, 2004.

IMF estimates indicate volatilities in Egyptian's remittances whether the inflow or outflow. The inflows have witnessed fluctuations from 1998 to 2003, and then started to increase steadily from 2004 to 2007 . The outflows have declined significantly over the period 1998 to 2002 , then increased in 2003 to decline again to its lowest level in 2004 and, then increased steadily over the years 2004 to 2007 (table 3)

Table (3) Inflow and outflow Egyptian remittances, compensation of employees and migrant's remittances

\begin{tabular}{|c|c|c|}
\hline \multirow{2}{*}{ Year } & $\begin{array}{c}\text { Egyptian remittances, compensation of employees and migrant's remittances } \\
\text { (US\$ million) }\end{array}$ \\
\cline { 2 - 3 } & Inflow & Outflow \\
\hline 1998 & 3370 & 39 \\
\hline 1999 & 3235 & 32 \\
\hline 2000 & 2852 & 35 \\
\hline 2001 & 2911 & 14 \\
\hline 2002 & 2893 & 79 \\
\hline 2003 & 2961 & 13 \\
\hline 2004 & 3340.7 & 57 \\
\hline 2005 & 5017.3 & 135 \\
\hline 2006 & 5329.5 & 108 \\
\hline 2007 & 5856 & \\
\hline
\end{tabular}

Source: IMF, balance of payments statistics, different years.

\section{FOURTH: SOURCES OF DATA}

The source of immigration data is the central agency for public mobilization and statistics (CAPMAS). As for data related to education, health and the gross domestic product, the source was the Egyptian human development report of 2008 and a series of basic data and national accounts for different years issued by Ministry of Economic Development.

\section{FIFTH: ESTIMATION OF ECONOMIC IMPACTS OF EGYPTIAN BRAIN DRAIN}

The estimation of loss resulting from brain drain as a proportion from the GDP includes estimation of the price elasticity of demand for the labor factor, calculation of the overall brain drain rate for Egypt and labor contribution in the domestic product.

1- $\quad$ Calculation of the elasticity of wages to the labor force.

The elasticity of wages regarding labor force for the years of study has been calculated, then the arithmetic mean for that (2.59) was used in the calculations.

2- Calculation of Egypt's migration rate according to the quality of migrants (skilled-unskilled) 
Due to the lack of data that determines the quality of immigrants in terms of skill, graduate and postgraduate immigrants has been deemed as skilled and, others with medium qualifications or less were deemed as unskilled. Then the migration rate for both skilled and unskilled labor was calculated using the following equations

$\mathrm{M}_{\mathrm{SLF}}=\mathrm{S} / \mathrm{S}+\mathrm{LF}$

$\mathrm{M}_{\mathrm{NSLF}}=\mathrm{NS} / \mathrm{NS}+\mathrm{LF}$

where MSLF and MNSLF refers to the migration rate of skilled and unskilled labor respectively, S and NS refers to the size of skilled and unskilled labor, while LF refers to the labor force.

3- Calculation of labor contribution in the domestic product.

As in (Dollar \& Kraay, 2002 and Mishra, 2006), the labor contribution in the domestic product was considered equal to 0.70 , the contribution of skilled and unskilled labor in the domestic product was calculated respectively using the following equations:

$\mathrm{L}_{\mathrm{SGDP}}=\mathrm{L}_{\mathrm{GDP}} * 0.28$

$\mathrm{L}_{\mathrm{NSGDP}}=\mathrm{L}_{\mathrm{GDP}} * 0.42$

Where LSGDP and LNSGDP refer respectively to the contribution of skilled and unskilled labor in the domestic product and LGDP refers to the contribution of all labor in the domestic product.

\section{Loss resulting from educating migrants}

The cost of educating one student per year was considered at 1500 pounds for school years and, for university and post graduate at 3000 pounds per year. Also, the period for obtaining a masters degree was set to five years, and for obtaining both Master and $\mathrm{PhD}$ for ten years, as well as the distinction between graduates in medicine, pharmacology, engineering and dentistry and other graduates because the study period is different (from an interview with the Minister of Education). The cost of obtaining a master's degree was calculated to equal the cost of obtaining the higher qualifications with an increase of 5 years. The cost of obtaining a PhD degree was divided into two parts i.e. Cost of obtaining the higher qualification inside Egypt and the scholarship period for the doctoral degree from abroad, assuming that migrants who hold $\mathrm{PhD}$ degrees must have obtain their degrees from abroad and, assuming that the cost of obtaining a doctoral degree abroad equals one hundred thousand dollars (Former Minister of higher Education, published information on the internet).

Table (4) Estimation of losses resulting from education expenditures on migrants

\begin{tabular}{|c|c|c|c|c|c|c|c|c|}
\hline Year & $\mathbf{1}$ & $\mathbf{2}$ & $\mathbf{3}$ & $\mathbf{4}$ & $\mathbf{5}$ & $\mathbf{6}$ & $\mathbf{7}$ & Total \\
\hline 1998 & 420030 & 3909510 & 6892800 & 2797860 & 701760 & 526320 & 7890500 & 23138780 \\
\hline 1999 & 320580 & 2983860 & 5260800 & 2386410 & 598560 & 448920 & 7224000 & 19223130 \\
\hline 2000 & 284310 & 2646270 & 4665600 & 2304120 & 577920 & 433440 & 5009500 & 15921160 \\
\hline 2001 & 376740 & 3506580 & 6182400 & 2550990 & 639840 & 479880 & 7181000 & 20917430 \\
\hline 2002 & 320580 & 2983860 & 5260800 & 2550990 & 639840 & 479880 & 6944500 & 19180450 \\
\hline 2003 & 195390 & 1818630 & 3206400 & 658320 & 165120 & 123840 & 2236000 & 8403700 \\
\hline 2004 & 234000 & 2178000 & 3840000 & 2304120 & 577920 & 433440 & 2472500 & 12039980 \\
\hline 2005 & 229320 & 2134440 & 3763200 & 2386410 & 598560 & 448920 & 3870000 & 13430850 \\
\hline 2006 & 245700 & 2286900 & 4032000 & 1892670 & 474720 & 356040 & 2666000 & 11954030 \\
\hline 2007 & 231660 & 2156220 & 3801600 & 1892670 & 474720 & 356040 & 3117500 & 12030410 \\
\hline Total & 2858310 & 26604270 & 46905600 & 21724560 & 5448960 & 4086720 & 48611500 & 156239920 \\
\hline
\end{tabular}

1- Cost of medicine graduate migrants

2- Cost of medicine of pharmacology, dentist, veterinary medicine and engineering migrants

3- Cost of graduate migrants not included in columns (1) and (2)

4- Cost of $\mathrm{PhD}$ migrants

5- Cost of Master migrants

6- Cost of high diploma migrants

7- Cost of pre university graduate migrants 


\section{Loss resulting from health expenditures on migrants}

The Egyptian per capita health expenditures was calculated from the overall health expenditures, then the cost of health care per immigrant prior to his immigration through calculating the age at the time of immigration , hence the losses incurred by Egyptian economy as a result of health spending on immigrants were calculated.

Table (5) Estimation of losses resulting from health spending on migrant labor

\begin{tabular}{|c|c|c|c|c|c|c|c|}
\hline \multirow{2}{*}{ Year } & \multicolumn{7}{|c|}{ Costs of emigrants who } \\
\hline & Less than 20 years & $20-$ & 30 - & $40-$ & $50-$ & $60-$ & Total \\
\hline 1998 & 280447 & 338970 & 770649 & 730089 & 318690 & 105457 & 2544301 \\
\hline 1999 & 174938 & 297638 & 646300 & 492014 & 213814 & 15793 & 1840498 \\
\hline 2000 & 162954 & 203692 & 607134 & 473091 & 260200 & 68335 & 1775406 \\
\hline 2001 & 161741 & 156524 & 511311 & 328700 & 186524 & 16957 & 1361756 \\
\hline 2002 & 81297 & 90925 & 239613 & 288820 & 94134 & 41718 & 836508 \\
\hline 2003 & 92507 & 80944 & 323776 & 260177 & 165357 & 30065 & 952825 \\
\hline 2004 & 998331 & 1497497 & 3930930 & 4717116 & 2059059 & 162229 & 13365162 \\
\hline 2005 & 161928 & 169178 & 541370 & 522035 & 212681 & 31419 & 1638611 \\
\hline 2006 & 91552 & 82728 & 478718 & 531112 & 309402 & 14339 & 1507850 \\
\hline 2007 & 73904 & 121050 & 553007 & 711009 & 224261 & 91106 & 1774336 \\
\hline
\end{tabular}

The overall economic impacts on the Egyptian economy due to labor emigration

Table (6) reflects the aggregate losses and gains resulting from Egyptian labor migration during the period $1998-2007$.

Table (6) Total losses and gains of labor migration $1998-2007$

\begin{tabular}{|c|c|c|c|c|c|c|c|}
\hline Year & $\mathbf{1}$ & $\mathbf{2}$ & $\mathbf{3}$ & $\mathbf{4}$ & $\mathbf{5}$ & $\mathbf{6}$ & $\mathbf{7}$ \\
\hline 1998 & 12.93 & 5.75 & 1.15 & 12.07 & 6.04 & 23138780 & 2544301 \\
\hline 1999 & 13.84 & 6.15 & 1.23 & 12.92 & 6.46 & 19223130 & 1840498 \\
\hline 2000 & 15.30 & 6.80 & 1.36 & 14.28 & 7.14 & 15921160 & 1775406 \\
\hline 2001 & 16.14 & 7.17 & 1.435 & 15.07 & 7.53 & 20917430 & 1361756 \\
\hline 2002 & 17.05 & 7.58 & 1.516 & 15.91 & 7.96 & 19180450 & 836508 \\
\hline 2003 & 18.79 & 8.35 & 1.67 & 17.54 & 8.77 & 8403700 & 952825 \\
\hline 2004 & 21.84 & 9.71 & 1.941 & 20.38 & 10.19 & 12039980 & 13365162 \\
\hline 2005 & 24.23 & 10.77 & 2.154 & 22.62 & 11.31 & 13430850 & 1638611 \\
\hline 2006 & 27.80 & 12.35 & 2.471 & 25.94 & 12.97 & 11954030 & 1507850 \\
\hline 2007 & 32.90 & 14.62 & 2.925 & 30.71 & 15.36 & 12030410 & 1774336 \\
\hline
\end{tabular}

(1) The direct losses from migration (Egyptian Pounds billion).

(2) Immigrants Gains (Egyptian Pounds billion).

(3) Factors owner losses (Egyptian Pounds billion).

(4) Losses including opportunity cost of brain drain (Egyptian Pounds billion).

(5) Total Egyptian economy losses excluding opportunity cost of brain drain (Egyptian Pounds billion).

(6) Losses from education spending on migrants (Egyptian Pounds).

(7) Losses from health spending on migrants (Egyptian Pounds).

\section{SIXTH: RESEARCH FINDINGS AND RECOMMENDATIONS}

The researcher has managed to analyze and estimate the economic effects of labor emigration in the Egyptian economy. Due to the lack of some data necessary for the estimation, some assumptions were adopted in the process. Also, the study due to lack of data was not able to estimate the Egyptian economy's losses as a result of loosing possible tax revenues because of emigration. Thus, the researcher sees the need to carry out more research on various aspects of this vital issue to avoid the shortcomings of the current research. Still, estimates have emphasized growing losses generated by the Egyptian labor emigration, especially by brain drain. No doubt that this 
reflects negatively on the economic and social development from various angles and that numbers of measures and policies must be adopted to stop this drain by addressing the causes of labor migration or rather, the existing properties of the labor expelling country mentioned in the research. Also, efforts must be made to ensure that data related to immigration is always available, updated and estimated by official bodies having human, financial and technical capabilities for this task.

\section{AUTHOR INFORMATION}

Dr. Hisham Handal Abdelbaki is an associate professor of Economics. He has got his BSc in Economics and Master Degree in Economics from university of Mansoura, Egypt and has got his PhD in Economics from Bradford University, UK. His interested areas are macroeconomic analysis, Social accounting Matrix, Income distribution, public policy, economic reform in developing and transition countries. At the present, Dr. Abdelbaki works at University of Bahrain, Bahrain.

\section{REFERENCES}

1. Abdelbaki, H. (2008), "How Can We Maximize Our Benefits From FTA With US: An Applied Study of Bahrain", Journal of Strategic Studies, Bahrain centre for studies and research, Vol. 4, No. 12, Summer 2008, Bahrain (in Arabic).

2. Adelman, I and J. E. Taylor, (1990),"Is structural Adjustment with a Human Face Possible? The case of Mexico", Journal of Development Studies, Vol. 26, pp. 387 - 407.

3. Aiyagari, et al, (1998),"Transaction Services, Inflation, and Welfare", Journal of Political Economy, Vol. 106, pp. $1274-301$.

4. Borjas, G. J., (1995),"The Economic Benefit from Immigration", Journal of Economic Perspectives, No. 9 , pp. 3-22.

5. $\quad$ Burgess, R., and V., Haksar, (2005),"Migration and Foreign Remittances in the Philippines", IMF Working Papers, No. WP/05/111, International Monetary Fund, Washington DC, June.

6. Central Agency for Public Mobilization And Statistics (CAPMAS), Statistical Yearly Book, different issues.

7. $\quad$ Carrington, W. J. and E. Detragiache, (1998),"How Big Is the Brain Drain", IMF Working Paper, No. WP/98/102, Washington D.C.

8. Chami, R. and others (2008)," Macroeconomic Consequences of Remittances", IMF Occasional Paper, No. 259, Washington D.C.

9. Chellaraj, G., Maskus, K. E. and A. Mattoo, (2006),"Skilled Immigration, Higher Education, and U.S. Innovation" in Ozden, G., and M. Schiff (eds.);" International Migration, Remittances, and The Brain Drain" A co-publication of The World Bank and Palgrave Macmillan, The World Bank, Washington D.C.

10. Cooley T. F. and G. D. Hansen, (1991),"The Welfare Costs of Moderate Inflations", Journal of Money, Credit and Banking, Vol. 23, pp. $483-503$.

11. Docquier F., O. Lohest and A. Marfouk, (2005),"Brain Drain in Developing Regions (1990 - 2000)", mimeo. CADRE. University of Lille, and Research Program on International Migration and Development. International Trade Unit. Development Economics Research Group (DECRG), World Bank, Washington, DC.

12. Docquier, F., and A. Marfouk, (2006),"International Migration by Education Attainment, 1990 - 2000", in Ozden, G., and M. Schiff (eds.);" International Migration, Remittances, and The Brain Drain" A copublication of The World Bank and Palgrave Macmillan, The World Bank, Washington D.C.

13. Dollar, D. And A. Kraay, (2002),"Growth is Good for the Poor", Journal of Economic growth 7, pp. 195 225.

14. Egyptian economy report, "Way of Egyptian Economic Growth", Economic researches forum, Egypt, December, 2004 (in Arabic).

15. Egyptian human development report (2008), Ministry of Economic Development.

16. Glytsos, N. P., (1993),"Measuring the Income Effects on Migrant Remittances: A Methodological Approach Applied to Greece", Economic Development and Cultural Change, Vol. 42, pp. 131 - 68.

17. Hague, N. and S. Kim, (1995),"Human Capital Flight: Impact of Migration on Income and Growth", IMF Staff Papers, No. 42, pp. 577 - 607. 
18. International Monetary Fund (IMF), Balance of Payments Statistics, Different Years.

19. Lucas, R. E., (1987),"Models of Business Cycles", Yrjo Johnsson Lectures (Oxford: Basil Blackwell).

20. Lucas, R. E., (1988),"On the Mechanics of Economic Development", Journal of Monetary Economics, No. 22, pp. $3-42$.

21. Mishra, P., (2006),"Emigration and Brain Drain: Evidence from the Caribbean", IMF Working Paper, No. WP/06/25, Washington D.C.

22. Radwan, S. (2002),"Labor and Unemployment in Egypt: Traditional Problems and untraditional solutions", Working paper to the Egyptian Centre for Economic Studies, No. 70 (in Arabic).

23. Romer, P. M., (1986),"Increasing Returns and Long -run Growth", Journal of Political Economy, No. 94, pp. $1002-37$.

24. (1987),"Crazy Explanations for the Productivity Slowdown", in Fischer, S., (ed.), NBER Macroeconomic Annual, (Cambridge, Massachusetts: MIT Press).

25. Saad Hassan, (2005),"Science and Technology in Arab Countries", study available on http://www.bibalex.org/CSSP/presentations/Attachments/1 (in Arabic).

26. World Bank, statistics, country profile, Egypt, 2006. 